\title{
Public Health Education
}

National Cancer Institute

\section{Source}

National Cancer Institute. Public Health Education. NCI Thesaurus. Code C18975.

Health education aimed at the general public 